DOI Number: 10.30520/tjsosci.553133

\title{
COMPARING BRITISH AND CARIBBEAN NATIONHOOD IN THE LONELY LONDONERS
}

Cengiz KARAGÖZ ${ }^{1}$

\begin{abstract}
Concepts of nation and nationalism have been among mainly debated points in the fields of social sciences since the spread of nation-states in Europe which goes back to especially the last decades of the nineteenth century and the first decades of the twentieth century. However, these concepts have been discussed not only among the European nations but also among the Third World countries which gained their independence and which were left by their native citizens who wished to immigrate to the European metropolises because of a variety of reasons and attractions. As a member of such immigrants from the Caribbean islands who floated into London after the Second World War, Sam Selvon touches upon the perceptions of nation and nationalism in The Lonely Londoners by reflecting these concepts from the viewpoint of the British nation and the Caribbean nation in the light of the Caribbean immigrants in Britain through different norms which play the basic role in defining a nation. Selvon can be thought to assert that while the British society bases its principles in defining a nation on discrimination and racial characteristics, particularly its superiority over the black immigrants and nations, the Caribbean immigrants identify these norms by emphasizing their common cultural elements and their potentials rather than racial and ethnic divisions and by adapting themselves to their collectively generated and fused values over time.
\end{abstract}

Keywords: Selvon, Nation, Race, Britain, Caribbean, Immigrants, London

\section{INTRODUCTION}

Nation-states and national movements were clearly observed to be significant issues in the last decades of the nineteenth century and in the initial decades of the twentieth century which began to shape the boundaries of certain primary states of Europe whose collective souls were situated within the concept of nation in order to keep their citizens' solidarity alive. However, it was not so obvious whether the system of nation-states proved to be a definite solution for the problems of each citizen of European states due to some changes in the social structures of those nations in the upcoming decades. Such changes raised sophisticated questions concerning what can be accepted as unchangeable principles that define the concept of nation or whether there exist such standard criteria determining the structural features of a nation as well as whether this concept can be redefined and regenerated in accordance with immigration movements across the world nations.

As for how a nation can be defined, two general approaches can be summarized in such a way that the first one is concerned with "political, civic and territorial terms", especially being a citizen who lives within the borders of a state after being born there, rather than "race,

\footnotetext{
${ }^{1}$ Dr. Lect., Namık Kemal University, School of Foreign Languages, ckaragoz@nku.edu.tr
} 
ethnicity and religion while the second approach focuses on the notion that "race, ethnicity, history and other cultural factors" can be substantive enough to clarify a nation even though its members live away from their birth territory and other members (Kumar 2006: 412). When it comes to how a nation can be made clear if minority groups desire to identify themselves with the dominant group's national identity, if the dominant group does not count this minority group's members as members of their nation, or if the minority group does not accept themselves as members of the dominant group's nation even when the dominant group is willing to approve of the minority group's national membership to their nationhood, the issue becomes a bit subtle and confusing. Discussing the conception of Benedict Anderson on one of the essential elements of nation, Barker lays emphasis on the point that "In particular, the mechanization of printing and its commercial dissemination 'fixed' a vernacular language as the 'national' language and in so doing made a new imagined national community possible." (2004: 99). Even this element of nation poses other mysteries to its members given that some citizens know more than one language and can communicate with more than one nation easily although they live in a foreign country, forging strong ties with more than one nation and becoming very familiar with cultural and traditional values of two or more societies.

After the second half of the twentieth century, ethnic conflicts implied that the main argument of nation have switched from racial issues to ethnic ones in that the more mobility between nations have arisen, the more discussions have been made in order to bring up problems and ways of solutions for those concepts. While race is often associated with physical features "such as skin colour, facial features, hair texture, body type, and so forth", ethnicity generally refers to features based on cultural origins "such as language, religion, or nationality" (Hunt 2006: 490). Thus, it can be argued in the light of these definitions that if racist notions are prevalent in a society, ethnic discrimination already exists in that society because encounters between nations are initiated physically and face to face, causing racist nations to evaluate other people of foreign racial roots according to their skin colours. As soon as foreign people are realized to belong to another foreign race, their language, religion and cultural constituents also begin to be denied and accepted as strange and contemptible.

Claiming that "One of the things which happens in England is the long discussion, which is just beginning, to try to convince the English that they are, after all, just another ethnic group", Hall's basic focus is on the idea that national identities will be more acutely defined in the upcoming decades of the twenty-first century or in the future in Britain like other Western countries in which various ethnic groups have had to settle with common purposes (1997: 21). Most possibly, Britain as an imperialist country feels that its whiteness must be sharper and more manifest against black immigrants whose racial identities have retired from the scene in order to cause ethnic identities to lead the way for new conflicts between the colonialist nations and the colonized ones. As Lemert puts it, "Ethnic differences are most acute when the prevailing nation-state is unable to manage the conflicts that inevitably ensue when established groups of the region depend on the aliens to satisfy their need for cheap and plentiful labor." (174-175). According to what Hall asserts above, it seems that Britain will appear as a new ethnic-state that is based on certain cultural attributes rather than a nationstate that is based on general racial characteristics.

The current argument on the emergence of the British state tending to underline ethnic identities has to concentrate on the period in which a large number of immigrants attempted to arrive in Britain with great ambitions and hopes to be in pursuit of disposing themselves of difficulties and troubles which have remained from the colonial period and which emphasizes 
the beginning of racial conflicts in respect to the black immigrants' existence in Europe being indicative of the severe ethnic clashes in the forthcoming decades. The half a million Caribbean immigrants coming to Britain as permanent guests like other black immigrants of different continents in the following years of the Second World War "arrived largely in response to government advertising campaigns that were aimed at attracting workers, particularly to industry and the public sector" (Weedon 2004: 67). These campaigns seemed to be successful in attracting the attention of Caribbean people who were waiting to make use of such an opportunity to leave their marginal homeland and to settle in the British metropolis which they thought is located in the central place of the world. Such events in the post-war period eventually displayed the first signs of decadence of the nation-states whose national side had to be questioned deeply and in detail as a result of conflicts regarding to what extent those Caribbean and other black immigrants could have been included in the British national identity. Despite the fact that these immigration movements prompted the racist approaches and oppression to appear in Europe, not least in Britain, this process on the other hand denotes the first signs of ethnic discrimination which arose in the last period of the twentieth century and the initial years of the twenty-first century.

\section{British vs. Caribbean Nationhood in The Lonely Londoners}

The Lonely Londoners is one of the most commonly referred novels of Selvon among the outstanding literary products of the postcolonial literature and known for its implications as regards the constant flux of the Caribbean immigrants into the imperial centre of the British nation and their strains to earn their lives in the face of the persistent difficulties stemming from the colonialist outlook of the British population. These issues raise the subject matter of nation and nationalism from the viewpoint of the British and the Caribbean nations because Selvon's view on the concepts of nation and nationalism needs to be examined through classifying it as the British nationalism and the Caribbean nationalism.

Regarding what lies behind nationalism and its tendency to generate elimination and assimilation between societies, Benhabib thinks that "Nationalist ideologies and movements reject the constitutive 'otherness' at the source of all culture; more often than not, they seek to 'purge' the culture of its impure or foreign elements and thus render it whole again" (2002: 8). This definition of nationalism can be said to be just akin to the British nationalism because of its government's discriminatory policies and the white population's attitudes toward the black immigrants beginning from their arrival. These policies and perceptions of the British nation "have not only reproduced the class disadvantages present at the point of migration, but have restructured them within relations of racism and other political and economic exclusions" (Anthias et al., 2005: 54). These multiple exclusions of the black immigrants from the equal distributions of sources and basic human rights uncover an obvious demarcation between the British nation and others who were not included in its abstract frontiers although they were living within its geographical frontiers.

In The Lonely Londoners, Selvon is observed to narrate "episodes from the life of Moses Aloetta," living in Britain for ten years, Henry Oliver, also called Sir Galahad, as well as "the lives of the other African-Caribbean men with whom they associate" (Weedon 2004: 69). However, the novel should be handled with an examination into the relationship between the white British nation and the black immigrants, their incessant longing for their homeland, impossibility of these immigrants' integration with the white nation and being exposed to performing the roles provided by the British society. 
Aiming to stay in London provisionally and then to return to the Caribbean islands before arriving in London, these immigrants do not attempt to go back even though they do not know the precise reason for staying in London permanently, and this poses certain problems in classifying them within the lines of the British nation. To illustrate, the author mentions that:

Still, the station is that sort of place where you have a soft feeling. It was here that Moses did land when he come to London, and he have no doubt that when the time come, if it ever come, it would be here he would say goodbye to the big city. (2006: 5)

In spite of being preoccupied with leaving Britain after working for a while and making a lot of money in order to manage a comfortable life in the Caribbean territory, Moses cannot make this dream real. It has been ten years since his arrival in Britain, but he has not been able to succeed in making enough money to live a life that complies with his ambitions. This is the case which is almost the same as that of other Caribbean immigrants who cannot return to the native land notwithstanding their complaint of severe uneasiness and strains they have to bear in the British metropolis. Tolroy as a Jamaican who lives in London with his mother and wife can be exemplified in the novel as follows: "Every year he vowing to go back to Trinidad, but after the winter gone and birds sing and all the trees begin to put on leaves again ... is as if life start all over again, as if it still have time ..." (Selvon 2006: 137). The immigrants' harkening after the Caribbean land and their insistent desire to leave Britain display the barriers between the British nation and themselves which emerge as a result of not being able to live mentally in Britain. These so-called transient visitors cannot go beyond living physically there and meeting their daily needs, and thus only reflecting only a faint existence in the British nation. Their presence in the London city as a physical one brings up the complex issue of whether it is enough to belong to a nation only by spending time in its borders without having any purpose to develop that nation while longing for the native nation that is left behind, but that cannot be escaped spiritually.

In order to draw attention to the memories and collective experiences in history which are considered an indispensable part of a nation, Renan argues that:

A nation is a soul, a spiritual principle. Two things, which in truth are but one, constitute this soul or spiritual principle. One lies in the past, one in the present. One is the possession in common of a rich legacy of memories; the other is present-day consent, the desire to live together, the will to perpetuate the value of the heritage that one has received in an undivided form. (1990: 19)

Then, if the Caribbean immigrants in London and other Western cities wish to preserve the common principles and values of their ancestors by recalling these ancestors' struggles and sufferings on the way to protecting their riches and civilization against any threats, it seems that there is not any convergent historical fact and collective memory between the Caribbean and the British nations due to exact differences in their past memories and ideals. In other words, when the Caribbean population recalls their ancestors' historical facts in the light of colonialism, they will most probably recognize that their ancestors were killed and tortured by the British and other Western colonizers under the pretence of bringing civilization to their native land and that their female ancestors were raped by the white men. Also, their natural resources were exploited by enslaving their grandfathers and carrying them to the Western territories. Considering these memories that prompt the Caribbean immigrants to have hostile feelings against the colonialist acts and nations while trying to construct an independent economic and political system in the Caribbean islands by following in their ancestors' footsteps, it can be understood that the reason why these immigrants move to London is not that they want to make Britain a politically and economically powerful country like the 
British society's ancestors, but that they desire to contribute to their individual goals and thus to take their profits to the Caribbean in order to develop it.

As opposed to the struggle of the Caribbean immigrants' ancestors to retain their native myths and cultural values by passing down such parts of their nation throughout the course of history, the ancestors of the white British population, like other European countries, engaged themselves with another historical course in which they experienced and wanted to develop very different ideas and innovations in favour of their own society even though these things operated in disfavour of the Caribbean and other black nations. As Stuart Hall makes a point about it, the Western people can be defined as "a society that is developed, industrialized, urbanized, capitalist, secular, and modern. Such societies arose at a particular historical period - roughly, during the sixteenth century, after the Middle Ages and the break-up of feudalism." (1992: 277). In addition to such historical events, Britain and other Western societies found themselves in an enormous change that covers such new developments as the Renaissance and Reformation that worked within the process of modernity. These developments forced the Western nations to be perpetually in search of raw materials and new markets, that is, finding new colonies with the intent of carrying such processes through by basing their ambitions on solely exploitation and oppression. These are the points which divide the ancestors of the British nation and those of the Caribbean nation in their historical consciousness and collective memories which have achieved in surviving until today in the current generations' minds.

Language becomes significant for the construction of a nation in that the closer communication is produced, the more common a language emerges, and also the more common language emerges, the closer communication is produced (Bauer 1996). Nevertheless, when the members of a society are able to speak the standard language of a nation but do not prefer to use it in its standard form, what does that mean for the intentions of such members toward the nation with which they live? By using "an authentic dialectal pattern of language in his early works", Selvon produces literary texts in which the elaborate structure of oral language prevails over the more formal and regular use of written language (Wyke 1991: 4). Despite being familiar with the formal English for many years dating back to the initial years of the British colonialism and being able to speak it in its formal form, the Caribbean immigrants in the novel consciously consult to using a dialect of English which does not conform to any linguistic norms and its formal use. Thus, language "becomes a tool with which a 'world' can be textually constructed. The most interesting feature of its use in post-colonial literature may be the way in which it also constructs difference, separation, and absence from the metropolitan norm." (Ashcroft et. al., 2004: 43). The author's choice of using that sort of language in The Lonely Londoners concerns the Caribbean population's endeavour to assert their decisiveness in separating their particular world from the British society's engagement and existence. If they cared about being accepted as members of the British nation by establishing a close communication with the white population, they would not generate a distinguishable and isolated world of their own in London by means of nonstandard English which verges on being unwilling to communicate sincerely and closely with the British citizens while engendering a Caribbean nation in the centre of an imperial land. This reluctance to join the British society by defying the commonly obeyed linguistic rules of English can be interpreted as a component that prevents them from an overall accession to the British nation and compels them to be restricted to their own national borders as the Caribbean community in the centre of Britain. 
Concerning the impact of the Caribbean immigrants' meeting in London upon their unity and establishing bonds between each other, Selvon claims in an interview that London becomes not only an imperial centre continuing to exploit members of once colonized nations but also a meeting place particularly for the Caribbean immigrants who never find the chance of communicating with each other in the islands such as Trinidad, Barbados, Jamaica owing to obvious problems and conflicts until they arrive in London, but they, after encountering each other in the city and having close connections, discern that they possess common painful memories and grieves which they mention during their dialogues (Nasta 2004). In a sense, the London city presents an opportunity for them to share their collective sufferings resulting from the colonial times with each other and free themselves from any sort of prejudice against members of the other islands in the Caribbean which leads to racial and ethnic conflicts among these islands. In a surrounding like Britain in which they also experience the same oppression and discrimination as all black immigrants and the fact of being totalized as black skinned people despite the fact that they vary as African, Caribbean, Trinidadian, Jamaican, Indian and so on, they focus on what their have in common by sympathising with each other and listening to each other's life stories in London and the Caribbean.

According to Selvon, "creolization, however imperfect, however unevenly mixed and credited at any given moment in the country's political discourse, is national culture, is the hope of strong populist culture capable of leading a people to higher development and happiness" (Harney 2006: 94). Consequently, he does not display any pessimistic perceptions on the creolized structure of the Caribbean culture and not consider that the Caribbean nation consists of a single culture which is independent of the influences of various racial populations. As for the concept of creole cultures and structures, it can be argued that "the actuality of Creole folklore in lived experience demonstrates that creolization cannot be reduced to an artificial construct, singularly imposed from above by the post-colonial nation state" even though creole entities have frequently been the signs and means of "nationalist" concerns and specific "political agendas" (Baron and Cara 2011: 4). In Selvon's conception of nation, cultural aspect of a nation cannot be reduced to a uniform one that is based on oppressive acts and policies of the nation-state and that is formed by ignoring a multitude of cultural elements in multicultural countries, so the Caribbean state covering a number of islands in which diverse racial groups exist cannot follow such a political method which holds decisions and formations dictated from the ruling body toward the ordinary individuals below. For him, the Caribbean societies have to learn how to notice their cultural prosperity and cultural fusion that arise out of an interactive communication between these different groups and that cannot be prevented from exchanging any components randomly. This cultural richness reveals the concept of nation for Selvon given that the sense of nationalism cannot be centred on racial roots especially for the Caribbean people when culture is observed to be a construct which surpasses the racial limitations.

A fete in St Pancras Hall in London held by Harris who is very fond of English manners and lifestyle and who has an inferiority complex can be given as an example to the revival of the Caribbean creole culture on entertaining occasions on which they drink and dance in the novel and can be supposed as an occasion or a pastime at night which is dominated by the Caribbean dance and music style by the Caribbean immigrants just like their children whose music and entertaining styles prevailed the London night clubs in real life in the upcoming decades after the 1970s (Harney 2006: 107). Through such activities which entertain them and provide these immigrants with transitory pleasure in the centre of racism and discrimination, nearly all of the Caribbean immigrants unconsciously take part in dancing and singing acts 
while contributing to the Caribbean culture's living in spite of the presence of very few immigrants like Harris in the novel who feels ashamed of the Caribbean values and tries to behave like the white British individuals, but whose presence does not prevent the Caribbean culture from being very dominant among the immigrants.

The author, for instance, relates the participation of Tanty, who is Tolroy's mother as a Jamaican woman, in the dancing accompanied by the traditional music played with the native songs and her voicing the excitement of joining in such an atmosphere in the following way:

'Tell this girl to unlace you: you know what they playing? "Fan Me Saga Boy Fan Me", and that is my favourite calypso. These English girls don't know how to dance calypso, man. Lady, excuse him,' and before Harris know what happening Tanty swing him on the floor, pushing up she fat self against him. The poor fellar can't do anything, in two-twos Tanty had him in the centre of the floor while she swinging she fat bottom left and right. (2006: 110)

The author does not mention that cultural elements in that fete pertain to certain islands like Trinidad, Jamaica, Barbados, and etc. by dividing these elements according to particular names of the islands; instead, they are reflected as the ones pertaining to the overall Caribbean cultural combination that embraces a huge number of components being a part of totally different cultures. Participants of such social events find themselves in a transformative process where they absorb some cultural values while lending several other elements to the creolized nature of the Caribbean culture. Selvon's Caribbean people insist "not on the rejection of European values or the recovery of Indian culture, but on a toe-to-toe stick fight with all cultural influence, and the cooptation and transformation of every influence into something creolized, something impure, something Trinidadian" (Harney 2006: 95). That is, Selvon's Caribbean culture cannot be separated from European impacts owing to the process of being influenced during the colonial period and spending years after immigrating to London, so the cultural structure in his mind can absorb and reshape each culture which it has contacted with while bringing about an intermingling of European, Indian, African, Caribbean and other cultures' pieces.

Possibly conceiving that the British nation cannot be provided an insight into irrespective of the black immigrants' troubles in their working lives, Selvon indicates the difference between the white and black workers in a way that will not equate the white workers to the black ones. In the novel, it is narrated about Moses that:

It happen while he was working in a railway yard, and all the people in the place say they go strike unless the boss fire Moses. It was a big ballad in all the papers, they put it under a big headline, saying how the color bar causing trouble again ... A few days after that the boss call Moses and tell him he sorry, but as they cutting down the staff and he was new, he would have to go. (2006: 8)

Even though Moses does not display any attitude and failure that would harm the white workers and that would decrease the standard of work, he is not wanted at the railway work because of his black skin, and he is fired very soon upon the demands of the white workers. In order to highlight the oppression and racism black workers have to face in Western countries and as a Caribbean intellectual, Cesaire confesses that "black people ... were doubly proletarianized and alienated: in the first place as workers, but also as blacks, because after all we are dealing with the only race which is denied even the notion of humanity" (Depestre 2000: 94). What Cesaire asserts with regard to double oppression of the black workers can be assigned to the Caribbean workers in the novel who are exposed to discrimination and even insulted by the white workers. When taken into account that Britain has had a strict class 
distinction throughout its historical development and that workers were located at the very bottom of this ranking, the Caribbean immigrants' arrival in Britain and their placement in the working class as new members can be claimed to operate for the benefit of the white British workers. The black Caribbean immigrants often had to occupy the low-paid and excruciating jobs at such places as factories, restaurants and railroads which the white workers did not want to work (Sivanandan 2008: 67). Therefore, the British workers, supposing that they found an opportunity to move up the social ladder unexpectedly by the emergence of the black workers after so many years of being exploited by their own white society, began to feel that they filled an upper rank in the society compared with the black workers and that they became more valuable than the black people. The novel proposes that it is their turn now to exploit the black ones situated below their status and to deny to these blacks any vital rights and equal opportunities which they immediately need to benefit from after settling in London without any certain arrangement and money.

It seems that Selvon envisages that political measures could be taken in order to keep those immigrants from entering Britain as he discusses the political issues being raised in the Parliament as follows: "... and big discussion going in Parliament about the situation, though the old Brit'n too diplomatic to clamp down on the boys or to do anything drastic like stop them from coming to the Mother Country" (2006: 2). This means that concerns about the penetration of a large number of the black immigrants into the British population cause the British deputies to be alerted to an impending danger which they begin to think has to be coped with through a set of relevant decisions and discussions. The Acts of 1968 and 1971 which aimed to restrict the number of black immigrants trying to enter Britain uncover the political attempts of the government to prevent the multiplication of such immigrants (Anthias et al., 2005: 34) and that the issue of the black immigrants and its solution methods gained a political dimension in the Parliament by exceeding the social and economic aspects. In several decades after the novel was written, Britain put aside its diplomatic side and openly declared that it would endeavour to stop the black immigrants' increasing number with the law amendment as a result of its fear that the country could be dominated by the increasing number of the black immigrants. Therefore, the author can be said to foresee the impending political restrictions produced in the Parliament by means of decisions that ordered the immigration rates to be controlled and declined while mentioning Britain as a "diplomatic" country in an ironic way.

The novel refers to the idea that one of the problems these immigrants try to deal with after arriving in London is that they do not have any place for staying and that they have to seek help from other immigrants like Moses who have been living there for years. Galahad, like other newcomers to Britain who consult to Moses first as soon as they step on London, is one of the immigrants coming from Trinidad who is offered to find Moses with the expectation that Moses can provide a house and a job for him. The author points out that "So what Moses could do when these fellars land up hopeless on the doorstep with one set of luggage, no place to sleep, no place to go?" (2006: 3). This problem causes such Caribbean immigrants to make up their own residential areas which are isolated and far away from the white society since they are not wanted and supplied with any staying place by the British citizens and since most of the landlords refused to provide them with houses for rent. "Housing ... became a more fiercely contested terrain. The immigrants had, of course, been consigned to slum houses and forced into multi-occupation. Now there were fears that they would move further afield into the white residential areas" (Sivanandan 2008: 101). The number of those who stayed in a room was often very high, and these numbers were changing due to the fact that most of these 
immigrants not possessing a static place of their own were staying in different houses which belong to Jamaican, Trinidadian and other Caribbean people every night. Their living areas were situated away from the centre of London toward the peripheral sites where they established small communities that involved only members of the Caribbean nation just as their native land like other once colonized countries was seen by the European colonizers as the periphery being far away from the Western central points.

In the novel, it is also disclosed that the Caribbean immigrants encounter racism and insulting attitudes because of the British nation's hostile feelings in the social life and in some settings which these immigrants abstain from entering. To illustrate, Moses warns Galahad of the existence of such insults by saying that "In America you see a sign telling you to keep off, but over here you don't see any, but when you go in the hotel or the restaurant they will politely tell you to haul - or else they give you the cold treatment" while giving the example of the Rendezvous Restaurant where black people are not served owing to their skin colour (Selvon 2006: 21). Unlike the white British citizens, the Caribbean people experience the drawback of being black and cannot meet their needs comfortably and freely because of the barriers constructed by the British society between themselves and those black people. During these years, it was frequently witnessed that the black immigrants were kept out of "clubs, bars and dance halls" which the white population could be allowed to enter and that they generally had to contend with racist attacks in Britain that occurred like ordinary events (McDowell 2013: 124). These facts underline the strong tendency of the British population to exclude the Caribbean immigrants from the white nation by exposing them to living in a restricted world whose borders were drawn very obviously and whose borders could not be surpassed.

As a black Caribbean immigrant who recognizes that black skin acts as a substantial obstacle to his dreams for London and who feels enormously weary of unceasing suffering caused by blackness, Glahad glances at his skin colour and says:

Colour, is you that causing all this, you know. Why the hell you can't be blue, or red or green, if you can't be white? You know is you that cause a lot of misery in the world. Is not me, you know, is you! I ain't do anything to infuriate the people and them, is you! Look at you, you so black and innocent, and this time so you causing misery all over the world. (Selvon 2006: 77)

The feelings and psychological state of Glahad uncover his inclination to identify himself with other black people who live thousands of miles away from him in any part of the world and to consider the matter of black colour detached from his individual problem by handling that problem from a collective standpoint. Fanon draws upon the colour problem for black people by suggesting "When European civilization came into contact with the black world, with those savage peoples, everyone agreed: Those negroes were the principle of evil" (2008: 147). As a matter of fact, this psychology of Galahad concerning his skin colour dates back to the very earlier period of centuries and to the initial encounter of the black nations with the colonialist powers that labelled them as the source of misery, wickedness and sin which pose impediment to the development of the white nations.

Bhabha refers to this conception while highlighting the possible problems which lie in the perception of nationhood where there exist both minorities and dominant groups:

It is the repetition of the national sign as numerical succession rather than synchrony that reveals that strange temporality of disavowal implicit in the national memory. Being obliged to forget becomes the basis for remembering the nation, peopling it anew, imagining the possibility of other contending and liberating forms of cultural identification. (1994: 161) 
The argument of Bhabha could be interpreted in terms of both the dominant groups in the imperial metropolises and the oppressed minorities that live together in the same realm with their utterly different historical facts and memories in their minds. The dominant community which includes those who are children and grand children of the ex-colonizer nations and who are brought up as part of these histories and memories keep on looking at the black immigrants from the eyes of their ancestors. Bhabha also sheds light upon the other side of the coin: "The barred Nation It/Self, alienated from its eternal self-generation, becomes a liminal signifying space that is internally marked by the discourses of minorities, the heterogeneous histories of contending peoples, antagonistic authorities and tense locations of cultural difference." (1994: 146). This notion can apply to the minority population of the Caribbean immigrants whose memories and collective histories greatly differ from those of the British community and clash with them in fundamental terms. The link of the Caribbean group to their native memories and ancestral values cannot be severed owing to their tendency to endure equivocally despite the assertive and predominant side of the Western civilization.

While laying emphasis upon the point that the concepts of race and nation for the British society have become so intertwined that they seem impossible to be separated, Gilroy also argues that "Blackness and Englishness are constructed as incompatible, mutually exclusive identities. To speak of the British or English people is to speak of the white ..." (1993: 27). According to Gilroy's definition of nation for the part of the British group, its borders are impenetrable and surrounded by the racial terms which aim to keep the black Caribbean people outside by assigning exact stereotypical roles to them which prevent from becoming inevitable members of the white community. Enoch Powell's contention that has to do much with "the difference between the merely formal membership of the national community provided by its laws, and the more substantive membership which derives from the historic ties of language, custom and "race" and that "the West Indian does not by being born in England, become an Englishman. In law, he becomes a United Kingdom citizen by birth; in fact he is a West Indian or an Asian still" (qtd. in Gilroy 1987: 46) can also be found to be one of the examples which illustrate the problem for the Caribbean immigrants to be accessed to the perimeters of the British nation. Considering the lack of any rule in law which protects the black immigrants' rights against any violation and illicit act, even the formal membership of the Caribbean people could be thought to be doubtful.

\section{CONCLUSION}

Selvon develops his conception of nation by reflecting the relationship between the British population and the Caribbean immigrants and shedding light on the discrete norms adopted by these two societies regarding what features a nation is supposed to possess. The author approaches this issue in relation to the general inclinations of these populations and their cultural and racial perceptions which play an important role in constructing a nation as well as ties between each other. According to Selvon, the Caribbean nation can be defined with cultural interaction and cultural sharing but without any reference to racial origins because of the structure of the Caribbean islands and the Caribbean immigrants' focus on their collective historical and cultural factors while in London, but the British nation cannot be discussed without pointing to its racial and racist perceptions given that it only takes skin colour and racial roots as the basic defining element of a nation as it can be understood out of the British society's discriminatory stance against the black immigrants. Even though the Caribbean immigrants live in London and leave their native islands behind, this presence in Britain does not verge on being a part of the British nation in reality, which the British citizens prove through their treatment of the Caribbean people like other black immigrants. The white 
population' approach to them openly displays that these immigrants are supposed to return to the Caribbean and not have any fitting space in the centre of Britain.

\section{REFERENCES}

Anthias, F., Yuval-Davis, N. and Cain H. (2005). Racialized Boundaries, London and New York: Taylor \& Francis e-Library.

Ashcroft, B., Griffiths, G. and Tiffin H. (2004). The Empire Writes Back. New York and London: Taylor \& Francis e-Library.

Barker, C. (2004). The SAGE Dictionary of Cultural Studies, London, California and New Delhi: SAGE Publication.

Baron, R. and Cara, A. C. (2011). Creolization as Cultural Creativity, the United States of America: The University Press of Mississippi.

Bauer, O. (1996). "The Nation," In Mapping the Nation by Gopal Balakrishnan, London and New York: Verso. p. 39-78.

Benhabib, S. (2002). The Claims of Culture, Princeton and Oxford: Princeton University Press.

Bhabha, H. K. (1994). The Location of Culture, New York: Routledge.

Depestre, R. (2000). “An Interview with Aime Cesaire," In Discourse on Colonialism by Aime Cesaire trans. by Robin D. G. Kelly, New York: Monthly Review Press. p. 79-95.

Fanon, F. (2008). Black Skin White Masks. Trans. Charles Lam Markman. London: Pluto Press.

Gilroy, P. (1987). There Ain't No Black in the Union Jack, London: Hutchinson.

--- (1993). Small Acts, London and New York, Serpent's Tail.

Hall, S. (1997). "The Local and The Global: Globalization and Ethnicity," In Culture, Globalization And The World System by Anthony King, Minneapolis: University of Minnesota Press. p. 18-41.

--- (1992). "The West and The Rest: Discourse and Power," In Formations of Modernity by Stuart Hall and Bram Gieben, UK: The Open University. p. 275-333.

Harney, S. (2006). Nationalism and Identity, Jamaica: University of the West Indies Press.

Hunt, D. (2006). "Race and Ethnicity," In The Cambridge Dictionary of Sociology by Bryan

S. Turner, New York: Cambridge University Press. p. 490-496.

Kumar, K. (2006). "Nationalism," In The Cambridge Dictionary of Sociology by Bryan S.

Turner, New York: Cambridge University Press. p. 412-413.

McDowell, L. (2013). Working Lives, UK: Wiley-Blackwell.

Nasta, S. (2004). "Sam Selvon with Susheila," In Writing Across Worlds by Susheila Nasta, London and New York: Taylor \& Francis e-Library. p. 12-19.

Renan, E. (1990). "What is a nation?" In Nation and Narration by Homi Bhabha, London: Routledge. p. 8-23.

Selvon, S. (2006). The Lonely Londoners, London: Penguin Group.

Sivanandan, A. (2008). Catching History on the Wing, London: Pluto Press.

Weedon, C. (2004). Identity and Culture: Narratives of Difference and Belonging. England: Open University Press.

Wyke, H. C. (1991). Sam Selvon's Dialectical Style and Fictional Strategy, Vancouver: University of British Columbia Press. 